How to Cite: Yaroshenko, O.G. (2021) Chemistry Textbooks as a Means of Supporting Cognitive Activity of General Secondary Education Students. Bulletin of the University of Karaganda - Chemistry, 102(2), 105-114. https://doi.org/10.31489/2021Ch2/105-114

UDC 372.854: 54 (075.8)

\author{
O.G. Yaroshenko* \\ Institute of Higher Education of the National Academy of Educational Sciences of Ukraine, Kyiv, Ukraine \\ ('Corresponding author's e-mail: yaroshenko_o@ukr.net)
}

\title{
Chemistry textbooks as a means of supporting cognitive activity of general secondary education students
}

\begin{abstract}
The article is devoted to such new direction of research as creating textbooks that provide competency-based approach to teaching Chemistry. A brief description of the results of the analysis of scientific literature on the research topic is presented. Based on them, it was concluded that it is necessary to develop a concept for creating Chemistry textbooks that would allow realizing the competence potential of academic subject. The main provisions of the author's concept are stated. According to them, the textbook should equally present its content and procedural components, which can ensure the formation of students' key and subject competencies. The author's rubrication of the textbooks is presented: "After mastering the material of the unit, you will be able...", "Remember! Pay attention!", "Chemistry is life: a naturalist's page", "Briefly about the main thing", "Erudite page", "Work in groups", "We work with media sources", "We know, we understand", and "We apply". The design of the units is briefly described. The embodiment of the conceptual provisions in school Chemistry textbooks for grades $8-11$ created by the author is revealed on specific examples.
\end{abstract}

Keywords: author's concept, Chemistry textbooks, competence-based approach, key competencies, main provisions of the concept, subject competence, textbook content and procedural components, textbook rubrication, unit design.

\section{Introduction}

New goals and content of complete general secondary education in Ukraine require the creation of modern educational books, among which textbooks are of main importance. Even the rapidly developing electronic teaching aids just supplement textbooks, contribute to the implementation of their functions, but in no way replace them. Currently in pedagogy there is a need to develop new approaches to the creation of textbooks, including Chemistry ones.

According to the Law of Ukraine "On Education", achieving the goal of secondary education "is provided by the formation of key competencies needed by every modern person for a successful life" [1]. According to the new paradigm, the content of teaching Chemistry "retains the time-tested basic core necessary for students' education and development; reveals the general cultural, humanistic nature of natural science knowledge; is based on leading worldview ideas of natural science" [2].

The competence-based approach was introduced in Ukrainian schools not long ago, but it has proved to be modern and effective. Therefore in the Chemistry curricula improved in 2017 it is noted that the main task of school chemistry education "is to form key and subject competencies by means of the academic subject. They also ensure developing students' values and worldview, which determine their behavior in real life situations" [1]. One of the characteristic features of these programs in comparison with the previous ones is the expression of learning outcomes in terms of competence. In the program section "Expected results of educational and cognitive activity", the main learning outcomes indicate the components of students' subject chemical competence to be formed: cognitive, activity and value. On the one hand, it is helpful for the authors of textbooks, since the circle of results in which the textbook plays an important role is outlined. But, on the other hand, in view of the fact that "thorough pedagogical research on the definition and justification of the competencies of modern textbooks, the allocation of requirements for the textbook as a comprehensive information model and learning tool in the context of implementing a competency-based educational approach" [3: 37], each author or group of authors have to theoretically substantiate the conceptual provisions of the textbooks they create.

The object of the research is the means of teaching Chemistry, and its subject is the structure, content, and methodological apparatus of a modern Chemistry textbook for students of general secondary education. The purpose of the article is to reveal the author's concept of creating modern Chemistry textbooks for students of Ukrainian schools. The tasks of the article is to substantiate the concept of creating a modern Chemistry 
textbook; describe the structure of the author's Chemistry textbooks; confirm implementation of provisions of the concept by examples from Chemistry textbooks for pupils of 8-11 classes.

The article is structured as follows: a brief description of the results of the analysis of scientific literature on the research topic; statement of the main provisions of the author's concept; description of the structure of the textbooks created on its basis; specific examples from the Chemistry textbooks created for students of grades 8-11 [4-7].

\section{Methods and Materials}

Taking into account the peculiarities of the research, methods of analysis of literature sources and generalization of the results were used; analysis of documents (curricula, programs, educational standards) was done. Induction and deduction, studying the experience of creating textbooks, conducting a search and pedagogical experiment were applied. The materials used in the study were school Chemistry curricula, Chemistry textbooks by domestic and foreign authors, as well as statistical data of the Ministry of Education and Science of Ukraine on the testing of school textbooks. Quantitative (in \%) indicators of students, teachers, and parents' satisfaction with school Chemistry textbooks recommended by the Ministry of Education and Science of Ukraine for use in the educational process were taken into account.

\section{Results and Discussion}

In the study state documents regulating secondary education, recent scientific publications by Ukrainian scientists on similar research topics (E. Baranovskaya, Y. Kodlyuk, O. Topuzov, etc.) served as a reference point in the development of the concept of creating textbooks on Chemistry on a competency basis. As the analysis has shown, Y. Kodlyuk has been studying the problem of textbooks for primary school children for a relatively long time. In one of the latest publications by the researcher [8], attention was focused on the informational, developmental, educational and motivational functions of a modern textbook for younger students. A. Polyakova listed the following didactic features of a school textbook: "functional features, the nature of the reflection of the content of education, structural features, and the technology of presentation of the means of guiding the cognitive activity of students" [8: 284]. We share the researcher's views on a school textbook as "a type of educational literature that represents knowledge and activities in a particular subject in accordance with state educational standards and curriculum requirements, taking into account the characteristics of this subject (its dominant function), type of school, age characteristics of students and is based on the dominant concept of learning" [8: 285]. In our opinion, this definition, on the one hand, has accumulated the classical views on the textbook developed in the 70s-80s of the twentieth century (Y. Babansky, I. Lerner, N. Skatkin, V. Kraevsky, etc.). On the other hand, such an interpretation makes it possible to supplement and clarify the definition of a textbook in accordance with the ongoing transformations in education. In view of the above mentioned, application of the competency-based approach in the educational process is considered the dominant concept of modern education. Y. Kodlyuk emphasized that the textbook "is a kind of scenario for the future learning process, as it captures not only the content of the subject, but also the main methodological approaches to its teaching, individual teaching methods (e.g., questions to analyze illustrations; samples of algorithms, instructions; sample records; instructions for doing practical tasks, etc.)" [8: 290].

The development of the main provisions for the creation of textbooks outlined by Y. Kodlyuk can be found in the publications of E. Baranovskaya and O. Topuzov. In particular, E. Baranovskaya pointed out that "the school textbook has to perform cultural, ethical and humanistic, reflective, personal and developmental functions in addition to its basic functions" [9: 10]. In the researcher's opinion, it is important for modern textbooks to focus on "humanitarian content of social sciences and humanities and to strengthen the humanitarian component in the content of the natural and mathematical cycle" [9: 6].

The following opinion of O. Topuzov seems to be constructive: "In order to create conditions for the formation of these components of personality competence in the process of learning the content of education, it is necessary to develop and implement an appropriate apparatus for learning, which creates additional burden on the non-textual component of the textbook" [3: 39]. Equally important is the view of the researcher that "a modern textbook, built on the competence basis should provide for the possibility of using a variety of organizational forms and methods of teaching and enrich their arsenal. In particular, it must create conditions for student self-educational activities" [3: 39].

Stará, M. Chvál, K. Starý pointed out the importance of high-quality school textbooks not only for schoolchildren and teachers, but also for students of higher teacher education institutions [10]. They explained it by the fact that it is sometimes difficult for students in pedagogical practice to fully select educational material, 
independently develop a methodology for its presentation, and test the knowledge acquired by schoolchildren. Therefore, student teachers often fully focus on the layout of textbooks and follow it.

It is known that the central link of educational activity is assimilation of knowledge as "complex intellectual activity of a person, including all cognitive processes (sensory perceptual, mnemological), providing reception, semantic processing, preservation and reproduction of the received material" [11].

Therefore, a textbook should perform different functions and at the same time be accessible for perception and understanding.

Based on the study of the researchers' interpretations of the creation and content of textbooks corresponding to the new paradigm of education using a competency-based approach, the following conclusions were made:

- a textbook is a leading and multifunctional teaching tool;

- educational material, teacher activities, and student activities are a kind of equilateral triangle that determines the content of the school textbook.

That is, conceptually, a textbook should equally represent the educational material, students' activities and teacher activities, remaining an important educational book for students.

Based on the above-mentioned, the content of a textbook is made up of educational material that reveals the core knowledge from various branches of Chemistry, selected and adapted for studying at school.

According to V. Beilinson, the basic and guiding function of textbooks is informational. "A textbook embodies the content of the academic subject and provides a minimum of means for its complete assimilation" [12: 34].

As the analysis of the research sources has shown, a school textbook is a multi-functional tool of teaching and learning, which, in addition to the informative functions, provides:

- motivation to study chemistry;

- a holistic model of the educational process;

- a logical and clear presentation, a thorough explanation of the new material based on a sufficient number of facts and illustrations;

- support for the educational process at all its stages: perception, memorization, application, assessment;

- conditions for the optimal use of individual, group and class educational activities of schoolchildren;

- an individual construct of the cognitive activity of each student;

- formation of cognitive skills and the ability to work with educational literature and other information resources;

- a methodological guideline for teachers.

V. Beilinson gave a clear explanation of the methodological purpose of a textbook: "not only students' activity is programmed in a textbook, but also the supposed activity of a teacher. A textbook not only provides material for teaching, but also defines the basic and main features of the method of working with it, guides the course of learning" [12: 39].

We are far from thinking that Chemistry textbooks should replace collections of problems and exercises (there are a number of manuals for that), or be book for reading on the subject under study. It has to correspond to its purpose. The main requirements for textbooks are: a) to correspond to the cognitive capabilities of students, which means to be available for their perception; b) to have a perfect methodological apparatus, which is easy for students to understand and convenient for a teacher to work with; c) to be of developmental nature, that is, provide the material for the performance of mental operations (analysis, synthesis, comparison, generalization, classification and others; d) to foster independent mastering of the educational material by students.

It is also important for textbooks to meet the basic assessment criteria. Concerning the issue, J. Papajani pointed out, "Evaluation checklists should have some criteria pertaining to the physical characteristics of textbooks such as layout, organizational, and logistical characteristics. Other important criteria that should be incorporated are those that assess a textbook's methodology, aims, and approaches and the degree to which a set of materials is not only teachable but also fits the needs of the individual teacher's approach as well as the organization's overall curriculum" [13: 8]. Due to the indicated multi-functionality, textbooks provide the implementation of the competence-based approach.

Let us reveal how the stated conceptual provisions were embodied in the school Chemistry textbooks designed by the author of the article. Initially, the author's heading of units was developed and then implemented, the same for all textbooks, from the eighth to the eleventh grades [4-7]. Figure 1 contains the names and symbols of these headings. 


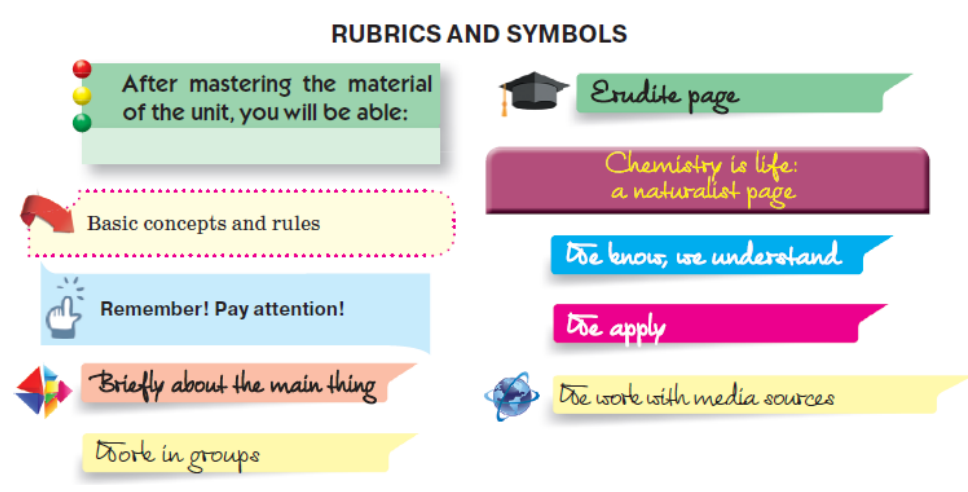

Figure 1. Rubrication of the author's textbooks on Chemistry

The content of the textbooks is compiled in full accordance with the current curriculum in Chemistry. We adhere to the point of view that textbooks are main educational books created primarily for students. Therefore, at the beginning of each topic basic knowledge that students should master in the process of studying the topic as well as skills, values and other qualities that allow the formation and development of subject competence in Chemistry are listed on coloured fly-titles. Methodologically, this is a concise list of expected learning outcomes on a topic. Therefore it serves as a personal educational construct for students, and for teachers it is a methodological guideline for conducting the educational process. It "will orient the teacher on achievement of the purpose of training on each theme of the program, will facilitate planning of the purposes and tasks of lessons, and will give the chance to develop adequate methodical approaches to conducting lessons as well as current and thematic assessment" [2].

Here is an example of the fly-title of topic 2 "Hydrocarbons" (grade 10).

In this theme you will learn about:

- classification of hydrocarbons;

- general formulas, structural isomerism and systematic nomenclature of alkanes, alkenes, alkynes, arenes;

- properties of alkanes, alkenes, alkynes, arenes;

- methods of production, application of hydrocarbons;

- relationships between homologous series of hydrocarbons;

- use of hydrocarbons and their impact on the environment.

After mastering the material on the topic, you will be able to:

- name alkanes, alkenes and alkynes according to the systematic nomenclature;

- give examples of saturated, unsaturated and aromatic hydrocarbons, structural formulas of their isomers;

- explain the essence of the structural isomerism of hydrocarbons; recognize the structural isomers of a substance;

- make molecular and structural formulas of hydrocarbons of a certain homologous series based on the general formula;

- compose reaction equations that describe the chemical properties of hydrocarbons;

- compare the structure and properties of hydrocarbons;

- solve problems on the derivation of the molecular formula of a substance according to the general formula of a homologous series and density or relative density; the mass, volume or quantity of the reagents or reaction products, justifying the chosen method of solution;

- draw conclusions about the properties of substances based on their structure and the structure of substances, taking into account their properties; on this basis to justify the use of hydrocarbons;

- understand the need to preserve the environment during the production and use of hydrocarbons;

- assess the fire hazard of hydrocarbons and the environmental consequences of violations of technologies for production and use of hydrocarbons and their derivatives" [6: 26].

In the textbooks there is no such heading as "Today in Class", which can be found in many other textbooks. It can be explained by the fact that it is more intended for teachers and is not personally oriented for students. Therefore, in order to impart positive motivation (personal colouring) to learning, in addition to flytitles, we use two more out-of-text components. The first is the announcement located at the beginning of each 
unit "After mastering the material of the unit, you will be able..." and the second announcement "Remember! Pay attention!", which are given in the text itself. For example, from the announcement to unit 11 "The degree of electrolytic dissociation. Strong and weak electrolytes. The concept of the $\mathrm{pH}$ of a solution", ninth-graders realize that after learning the material they will be able to "find out what is a quantitative indicator of electrolytic dissociation; get to know the classification of substances by the degree of electrolytic dissociation; learn about the factors affecting the degree of electrolytic dissociation; form an idea of the $\mathrm{pH}$ value; distinguish between $\mathrm{pH}$ alkaline, acidic and neutral; evaluate the $\mathrm{pH}$ value of solutions to determine the quality of food, cosmetics and other types of products" [5: 62].

"Remember! Pay Attention!" announcements concern:

- revising something previously learned, e.g., "Remember! Names of symbols of chemical elements, as well as proper names, are written in capital letters, and the names of substances formed by their atoms - in lowercase ( $\mathrm{H}$ - Hydrogen, $\mathrm{O}$ - Oxygen, $\mathrm{H}_{2}$ - hydrogen, $\mathrm{O}_{2}$ - oxygen)" [4: 7];

- short-term completion of a specific task in the course of working out educational material, e.g., "Use this pattern to find out: which of the elements of group II of the main subgroup - Magnesium or Calcium has more pronounced metallic properties; in Oxygen or Sulfur (group VI main subgroup) more pronounced non-metallic properties" [4: 52];

- clarifications to the main text e.g., "Amorphous is one that has no crystalline structure. Amorphous is a substance without a clear three-dimensional arrangement of structural particles" [4: 106];

- precautions when working with chemical substances e.g. "Remember that ethyne (acetylene) with air and oxygen forms explosive mixtures" [6: 55] and others.

The text of each unit is divided into logically complete blocks of educational information. The blocks have titles, from which students find out what the unit is about, and after studying it, they can give feedback. For example, unit 18 of the textbook for 11 grade "Compounds of non-metallic elements with Hydrogen. Features of aqueous solutions of these compounds, their application" is divided into seven blocks. They go under the following titles: physical properties of hydrogen chloride, physical properties of ammonia, features of aqueous hydrogen chloride solution, features of aqueous ammonia solution, ammonium hydroxide $\mathrm{NH}_{4} \mathrm{OH}$, the concept of ammonium salts, and qualitative reaction for the determination of ammonium ions in solutions.

The final informational part of the main text of each unit in the textbooks has the heading "Breifly about the main thing". In it, in a generalized way, with several rules, judgments, conclusions, the main things in the educational material of the unit are conveyed. As practice shows, students willingly work with this rubric, since it focuses on what should be preserved in long-term memory and will be used in the future.

In order for the textbook to be involved in the formation of the key competence of students' communication in the state language (or native one), to form the ability to work in a team and to develop leadership qualities, the column "Work in groups" was created. According to the curriculum, the subject content of the specified competence consists of the following skills: "to use chemical terms, concepts, symbols, modern Ukrainian scientific terminology and nomenclature in speech; give answers to the questions; substantiate the course and conditions of the chemical experiment; discuss the results of the study and draw conclusions; to take part in the discussion of issues of chemical content, to express one's opinion clearly, clearly and figuratively; compose an oral and written report on a chemical topic, and present it" [1]. It is obvious that during the study of Chemistry (as a rule, there are two lessons per week) the skills cannot be formed without the use of group educational activities. Whereas working in small groups, even at the stages of primary perception of new material, students are involved in educational communication, favorable for the formation of that and other competencies. Here an example of the content of the heading "Work in groups" in the above-mentioned unit 18 of the textbook for 11 grade is given.

Task 1 . Prove by mathematical calculations that it is necessary to collect ammonia in a test tube located upside down.

Task 2. Ammonia is sold in a dark glass container with a capacity of $150 \mathrm{ml}$ in pharmacies. Assuming that the density of ammonia is $1 \mathrm{~g}$ per $1 \mathrm{ml}$, calculate the amount of ammonia used to prepare the solution for one such vial.

Task 3. Calculate the relative density of hydrogen chloride in the air. How to collect this gas in a test tube properly?

Task 4. From the section, you learned what the solubility of ammonia in water is. Calculate the mass fraction of this substance in a solution made by dissolving 700 liters of ammonia in 1 liter of water, if the density of the solution is considered to be equal to $1 \mathrm{~g} / \mathrm{ml}$ [7: 96-97]. 
In addition, short-term group educational activities in the lesson of studying new material help to avoid a teacher monologue and promote the understanding and assimilation of new knowledge directly in the lesson, involving students in active cognitive activity, and intensifying the educational process.

The heading "Erudite Page" has an additional text that allows students to expand and deepen the content of the main material of the unit thanks to the information that is not provided by the program, but corresponds to the topic of the unit. The tasks of the rubric stimulate cognitive interest, motivate learning the history of science, develop thinking, and enhance patriotic education. For example, the main material of the unit on the structure of the atom (grade 8) contains information that, "The scientific assumption about the presence of neutrons in the nucleus was made by a theoretical physicist Dmitry Dmitrievich Ivanenko in 1932" [4]. "Erudite Page" contains some information about D.D. Ivanenko's life and activities in Ukraine, as well as about the period of his work at Lomonosov Moscow State University. It also tells that "the scientific merits of the physicist were highly appreciated by Nobel laureates Paul Dirac, Hideki Yukawa, Niels Bohr, Ilya Prigozhin, and Samuel Ting, who left their famous statements on the walls of Dmitry Dmitrievich Ivanenko's office at Lomonosov Moscow State University" [4: 58]. In the same unit, under the heading "Work with media sources" one of the tasks is formulated as follows "Find out what records were left by Nobel laureates P. Dirac, H. Yukava, N. Bohr, I. Prigozhin and S. Ting on the walls of D.D. Ivanenko's office. Write them down and discuss them in groups" [4: 58].

The attention of schoolchildren to modern sources of information as a means of independent mastering of additional knowledge and skills is attracted by the tasks under the heading "Work with media sources". Often, their implementation involves group work and relates to educational projects. Consider the example from unit 30 "Mineral fertilizers. The concept of acidic and alkaline soils" of the textbook for 11th grade.

1. From various sources learn about the top 10 largest producers of fertilizers in Ukraine (capacity, raw materials, and products).

2. Ask about the professions of employees of modern enterprises for the production of fertilizers, and educational institutions where the necessary qualifications can be obtained.

3. What means of environmental protection from pollution operate in enterprises producing mineral fertilizers? [7: 161].

"Creating a textbook always requires a clear and reasonable answer to the question: what types of problems (exercises) and in what minimum quantity should be in the textbook, and what should be included in an expanded and variable form in the corresponding collection" [12: 38-39]. Adhering to this point of view, we do not overload the textbooks with exercises and tasks; in parallel with them, we created a collection of tasks and exercises, workbooks and notebooks for control and practical work. The assignments and exercises in the Chemistry textbooks are based on competence-based and activity-based approaches. Most of them are located in the final headings of the units entitled "We know and understand" and "We apply". The former contains tasks that require reproduction of knowledge or performing actions according to a model. Here is an example of tasks from paragraph 16 "The nature of chemical bonding and electronegativity of atoms of chemical elements" of the textbook for the 8th grade.

1. Formulate the definition of: a) chemical bond; b) electronegativity; c) completed energy level.

2. Explain how the structural particles of matter can acquire the completeness of the external energy level. What does it depend on?

3. Indicate which of the two elements is more electronegative: a) Nitrogen or Oxygen; b) Nitrogen or Hydrogen; c) Nitrogen or Lithium.

4. Explain why the electronegativity of atoms of inert elements is zero" [4: 96].

To fulfil the assignments under the heading "We apply", students need to apply the knowledge gained in standard or modified conditions. In the above-mentioned unit, the heading consists of the following tasks:

1. In which of the molecules: a) Oxygen; b) water; c) Hydrogen; d) hydrogen bromide - common electrons will be displaced to one of the atoms and why?

2. Specify a pair of symbols of elements whose atoms have the same number of unpaired electrons at the external energy level: a) Li and S; b) Mg and F; c) Li and F. Explain your choice using graphical electronic formulas.

3. Write down the symbols of the following chemical elements in ascending order of their electronegativity: Aluminum, Sulfur, Carbon, and Hydrogen.

4. Prepare questions or tasks on the topic of the unit to suggest them to classmates in class" [4: 96].

As it can be seen from the considered example, the tasks under the heading "We apply" are numbered consecutively in the textbooks, which is very convenient, since the answers are given at the end of the textbook, and students can do self-tests. 
Tasks for consolidating and applying the knowledge can also be found under the heading "Work in groups", for example:

1. To ensure that alcohols have more isomers than their corresponding alkanes, formulate all possible isomers of alcohol with the molecular formula $\mathrm{C}_{5} \mathrm{H}_{11} \mathrm{OH}$ (there should be 6 of them) and pentane.

2. Make one molecular formula of homologues: a) propane; b) methane; c) ethyn [6:22].

Each topic ends with a page "Assignments of different difficulty levels". The tasks help students to do self-assessment, monitor personal growth, and reflect on educational achievements.

It is well-known that a chemical experiment is an important means and method of teaching Chemistry. Therefore, the sequence of the teacher's performance in the lesson of demonstration experiments, the necessary explanation, as well as illustrations to them are displayed in the main text of the units so that, while working independently with the text of the unit, the students can mentally reproduce the experiment. Traditionally, Chemistry textbooks contain tasks and instructions for performing a school chemistry experiment: laboratory experiments and practical work. In the textbooks, they go under the heading "Chemistry is Life. Naturalist's Page". Description of laboratory experiments contains a list of equipment and substances, instructions for their implementation, which displays the sequence of actions, advice on the presentation of results. Since practical work has a different didactic purpose than laboratory experiments, textbooks contain only the name of the practical work and the texts of assignments for practical implementation. In the content of practical work on solving experimental problems, we strive to include a deliberately larger number of tasks than the students will complete in one lesson. It is aimed at students repeating the material they have covered, getting better prepared for practical work, conducting experiments on all the options of the proposed tasks in their minds. For example, in the Chemistry textbook for the 9th grade for practical work 2 "Solving experimental problems", five experimental problems were selected (three variants of tasks in each). It is illustrated by an example of experimental problem 3: "Carry out ion exchange reactions according to the given schemes.

Variant 1 . Sodium hydroxide $\rightarrow$ sodium sulfate $\rightarrow$ sodium chloride.

Variant 2. Chloric acid $\rightarrow$ sodium chloride $\rightarrow$ sodium nitrate

Variant 3. Cuprum (II) sulfate $\rightarrow$ Cuprum (II) chloride $\rightarrow$ Cuprum (II) hydroxide.

Justify the choice of reagents. Make up the corresponding molecular and ionic reaction equations [5: 85]. In practical work students perform only one of those variants that the teacher suggests.

In school textbooks, an important didactic function is performed by illustrative material. "Several factors should be considered, such as the clarity and coherence with which information in graphic visualisations is presented. A textbook layout that guides the learner through the depicted resources and enables the student to easily identify relevant information, includes visual and textual linking between related materials, and the instructional, didactical, technical and aesthetic quality of depicted visuals, to name only a few" [14: 56].

There are many illustrations in the textbooks. The choice of illustrative material is due to its didactic function. All illustrations correspond to the content of the educational material, help its perception, memorization and reproduction, contribute to the development of visual memory, and are used in performing tasks. For example, Figure 2 [4: 194] is an illustration of the experiment to identify the amphoteric properties of zinc hydroxide.

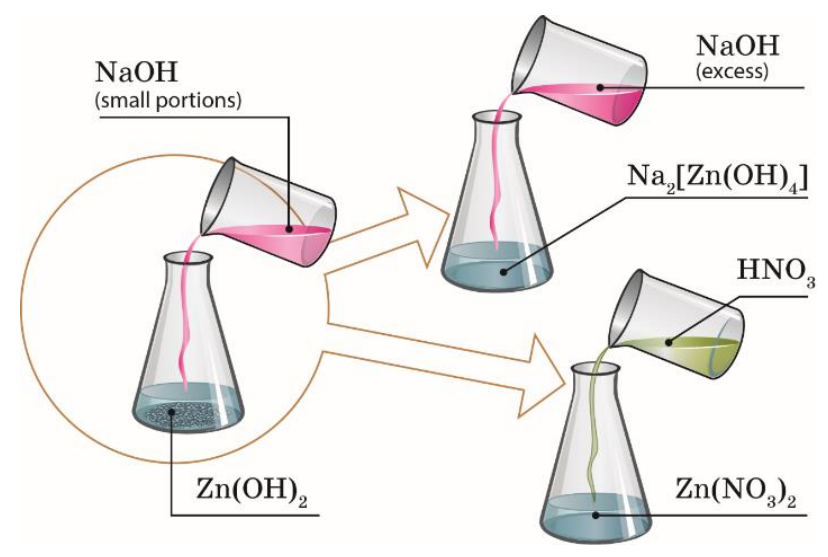

$a$ - extraction of zinc hydroxide; $b, c$ - dissolution of the precipitate $\mathrm{Zn}(\mathrm{OH})_{2}$

Figure 2. The sequence of the experiment on the detection of amphotericity of zinc hydroxide 


\section{Conclusions}

The reorientation of teaching Chemistry in modern secondary educational institutions from communicating knowledge to the formation of key and subject competencies determines the relevance of research on the problem of creating textbooks that correspond to this paradigm. As in the course of the study of research papers on the topic there was found lack of concept of creating textbooks that provide teaching Chemistry on a competence basis, and the educational process needed them; the author's concept of textbooks was created that allows to realize the competence potential of this academic subject.

The main provisions of the author's concept are the optimal combination of the content and procedural components of the textbook; taking into account the cognitive capabilities of students; the presence of a perfect methodological apparatus; the suitability of the textbook for use at all stages of the educational process such as perception, memorization, use, assessment; the possibility of conducting group educational activities along with individual and class work; a convenient navigator in the form of headings; modernity and attractiveness of design; and variety of illustrative material.

In accordance with the provisions of the concept, the headings of the author's textbooks of chemistry were substantiated and developed: "Work in groups" (contains tasks for short-term group work in the lesson of studying new material), "Chemistry is life: a naturalist's page" (a student experiment is described. "Briefly about the main" (a generalization of the material of the paragraph is made.) The headings "We know, we understan", "We apply" contain tasks and exercises differentiated by the level of students' cognitive activity. Additional material has been placed in the rubric "Erudite page", tasks involving use of media go under the heading "Work with media sources". In addition, an important motivational function is performed by coloured fly-titles for each educational topic and the following announcements "After mastering the material of the unit, you will be able..."; "Remember! Pay attention!" To use the visual memory of students, the main text of the units is divided into logically completed blocks of the educational information with colored titles; and various illustrative materials are used.

Rubrics of the units and the design of their layout serve as a convenient navigator for students while working with the textbooks. This conclusion is confirmed by the examples considered in the article from the author's Chemistry textbooks for $8-11$ grades.

The textbooks of Chemistry that were created on a competence basis do not leave room for authoritarian pedagogy. They provide students with an individual construct of cognitive activity, and give teachers methodological guidelines for planning and implementing the educational process on a competency-based approach. Learning by them involves various activities and communication.

\section{References}

1 Закон України «Про освіту» від 05.09.2017 № 2145-VIII. — URL: https://zakon.rada.gov.ua/laws/show/2145-19.

2 Хімія. 7-9 класи. Програма для загальноосвітніх навчальних закладів. Програма затверджена Наказом Міністерства освіти і науки України від 07.06.2017 № 804. - URL: https://mon.gov.ua/ua/osvita/Zagalna-serednya-osvita/navchalniprogrami/navchalni-programi-5-9-klas

3 Топузов О.М. Компетентнісні засади сучасного підручникотворення / О. Топузов // Українс. пед. журн. - 2015. № 3. 一 C. 36-47. — URL: http://nbuv.gov.ua/UJRN/ukrpj_2015_3_5.

4 Ярошенко О.Г. Хімія: підруч. для 8 кл. загальноосвіт. навч. закладів / О.Г. Ярошенко. - Київ: УОВЦ «Оріон», 2016. $256 \mathrm{c}$.

5 Ярошенко О. Г. Хімія: підруч. для 9 кл. загальноосвіт. навч. закладів / О. Г. Ярошенко. — Київ: УОВЦ «Оріон», 2017. $-224 \mathrm{c}$.

6 Ярошенко О. Г. Хімія (рівень стандарту): підруч. для 10 кл. закладів загальної середньої освіти / О.Г. Ярошенко. Київ: УОВЦ «Оріон», 2018. — 208 с.

7 Ярошенко О.Г. Хімія. 11 кл.: підр. для закл. загальної середньої освіти. - Київ: УОВЦ «Оріон», 2019. — 208 с.

8 Кодлюк Я. П. Концептуальні основи побудови підручника для початкової школи / Я.П. Кодлюк // Проблеми сучасного підручника. — 2014. — Вип. 14. — C. 284-292. — URL: http://nbuv.gov.ua/UJRN/psp_2014_14_34

9 Барановська О.В. Сучасний підручник у руслі гуманітаризації навчального процесу: основні акценти / О.В. Барановська // Проблеми сучасного підручника. - 2020. — Випуск 24. - C. 5-13.

10 Stará Ja., Chvál M., Starý K. The Role of Textbooks in Primary Education. E-Pedagogium. — 2017. — No. IV. — P. 60-69. https://e-pedagogium.upol.cz/pdfs/epd/2017/04/07.pdf

11 Зимняя И.А. Педагогическая психология: учеб. для вузов / И.А. Зимняя. - 3-е изд., пересм. - М.: Моск. психол.-соц. ин-т; Воронеж: НПО «МОДЭК», 2010. — 448 с.

12 Бейлинсон В.Г. Арсенал образования: учеб. кн.: проектирование и конструирование / В.Г. Бейлинсон. — 2 -е изд., испр. и доп. - М.: Мнемозина, 2005. - 399 с. 
13 Papajani J. The Evaluation of the EFL Textbooks Used in the High Schools of Elbasan, Albania. European Journal of Language and Literature Studies. — 2015. - Vol. 1, No. 1. — P. 7-15. http://journals.euser.org/files/articles/ejls_jan_apr_15/Josilda_Papajani.pdf

14 Behnke Y. How textbook design may influence learning with geography textbooks. Nordidactica — journal of humanities and social science education. - 2016. — No. 1. - P. 38-62. https://www.diva-portal.org/smash/get/diva2:1047511/FULLTEXT01.pdf; fulltext

\title{
О.Г. Ярошенко
}

\section{Химия окулығы жалпы орта білім беру мекемелері оқушыларының танымдық іс-әрекетін ұйымдастырудың құралы ретінде}

\begin{abstract}
Мақала зерттеудің жаңа бағытына, яғни оқушыларды құзыреттілік негізінде оқытуды қамтамасыз ететін оқулықтар жасауға арналған. Зерттеу тақырыбы бойынша ғылыми әдебиеттерді талдау нәтижелері қысқаша сипатталған, химия оқулықтарын құру тұжырымдамасын әзірлеу қажеттілігі айтылған, бұл оқу пәнінің құзыреттілік әлеуетін іске асыруға мүмкіндік береді. Авторлық тұжырымдаманың негізгі ережелері: оқушылардың танымдық мүмкіндіктерін ескеру; мінсіз әдістемелік аппараттың болуы; оқулықтың оқу процесінің барлық кезеңдерінде қолдануға жарамдылығы; топтық оқу қызметін ұйымдастыру мүмкіндігі; тақырыптар түріндегі ыңғайлы мәтін навигаторының болуы; дизайнның қазіргі заманға сай болуы; иллюстративті материалдың әртүрлілігі. Авторлық оқулықтардың рубрикасы ұсынылған. «Топпен жұмыс» айдарында жаңа материалды үйрену сабағында қысқа мерзімді топтық жұмыстарға арналған тапсырмалар берілген. Окушылардың тәжірибесі «Химия - өмір: табиғатты зерттеушінің парағы» айдарында сипатталған. Материалдың қысқаша мазмұны «Басты нәрсе туралы қысқаша» айдарында келтірілген. Тапсырмалар мен жаттығулар «Біз білеміз, түсінеміз», «Біз қолданамыз» атты айдарларға бөлінген. Қосымша материал «Эрудит беті» және «Медиадереккөздермен жұмыс» айдарында келтірілген. Параграфтардың дизайны қысқаша сипатталған. Параграфтар «Параграфтың материалын пысықтағаннан кейін сіз жасай аласыз» деген хабарландыруымен басталады. Параграфтардың негізгі мәтіні әртүрлі иллюстрациялық материалдармен және «Есіңізде сақтаңыз! Назар аударыңыз!» сияқты түрлі бейнелі материалдармен жабдықталған. Жаңа ұғымдар мен ережелер түрлі-түсті беттерде орналасқан. Автордың 8-11 сыныптарға арналған химия оқулықтарынан алынған нақты мысалдары тұжырымдаманың негізгі ережелерінің орындалуын растайды.
\end{abstract}

Кілт сөздер: химия окулығының авторлық тұжырымдамасы, параграфтарды жобалау, құзыреттілікке негізделген тәсіл, негізгі құзыреттер, тұжырымдаманың негізгі ережелері, пәндік құзыреттілік, оқулық тақырыбы, окулықтың мазмұны және процедуралық компоненттері, химия оқулығы.

\section{О.Г. Ярошенко}

\section{Учебник химии как средство организации познавательной деятельности учащихся учреждений общего среднего образования}

Статья посвящена новому направлению исследований - созданию учебников, обеспечивающих обучение учащихся на компетентностной основе. Кратко описаны результаты анализа научной литературы по теме исследования, отмечена необходимость разработки концепции создания учебников химии, позволяющей реализовать компетентностный потенциал этого учебного предмета. Основными положениями авторской концепции являются: учет познавательных возможностей учеников; наличие совершенного методического аппарата; пригодность учебника к использованию на всех этапах образовательного процесса; возможность организации групповой учебной деятельности; наличие удобного навигатора текста в виде рубрик; современность дизайна; разнообразие иллюстративного материала. Представлена рубрикация авторских учебников. Рубрика «Поработайте группами» содержит задания для кратковременной групповой работы на уроке при изучении нового материала. Ученический эксперимент описан в рубрике «Химия - это жизнь: страница природоисследователя». Обобщение материала приведено в рубрике «Коротко о главном». Задания и упражнения дифференцированы на рубрики «Знаем, понимаем» и «Применяем». Дополнительный материал вынесен в рубрики «Страница эрудита» и «Работаем с медийными источниками». Кратко описан дизайн параграфов. Параграфы начинаются анонсом «Проработав материал параграфа, вы сможете». Основной текст параграфов скомпонован в логически завершенные блоки учебной информации, сопровождается разнообразным иллюстративным материалом и анонсами «Вспомните! Обратите внимание!». Новые понятия и правила расположены на цветных плашках. Конкретными примерами из созданных автором учебников химии для 8-11 классов подтверждено воплощение основных положений концепции. 
Ключевые слова: авторская концепция учебника химии, дизайн параграфов, компетентностный подход, ключевые компетентности, основные положения концепции, предметная компетентность, рубрикация учебника, содержательная и процессуальная составляющие учебника, учебник химии.

\section{References}

1 Zakon Ukrainy "Pro osvitu" [The Law of Ukraine "On Education"]. (n.d.). zakon.rada.gov.ua. Retrieved from https://zakon.rada.gov.ua/laws/show/2145-19 [in Ukrainian].

2 Khimiia. 7-9 klasy. Prohrama dlia zahalnoosvitnikh navchalnykh zakladiv. Prohrama zatverdzhena Nakazom Ministerstva osvity i nauky Ukrainy vid 07.06.2017 № 804. [Chemistry. Grades 7-9. The program for secondary schools. The program is approved by the Order of the Ministry of Education and Science of Ukraine dated 07.06.2017 № 804]. mon.gov.ua Retrieved from https://mon.gov.ua/ua/osvita/zagalna-serednya-osvita/navchalni-programi/navchalni-programi-5-9-klas [in Ukrainian].

3 Topuzov, O.M. (2015). Kompetentnisni zasady suchasnoho pidruchnykotvorennia [The competence basis for the creation of modern textbooks]. Ukrainskyj pedahohichnyj zhurnal - Ukrainian pedagogical journal, 3, 36-47. Retrieved from http://nbuv.gov.ua/UJRN/ukrpj_2015_3_5. [in Ukrainian].

4 Yaroshenko, O.H. (2016). Khimiia: pidruch. dlia $8 \mathrm{kl}$. zahalnoosvit. navch. zakladiv. [Chemistry: a textbook for gr. 8 of general educational institutions]. Kyiv: UOVTs "Orion" [in Ukrainian].

5 Yaroshenko, O.H. (2017). Khimiia: pidruch. dlia 9 kl. zahalnoosvit. navch. zakladiv [Chemistry: a textbook for gr. 9 of general educational institutions]. Kyiv: UOVTs "Orion" [in Ukrainian].

6 Yaroshenko, O.H. (2018). Khimiia (riven' standartu): pidruch. dlia 10 kl. zakladiv zahalnoi serednoi osvity [Chemistry (standard level): textbook for gr. 10. of institutions of general secondary education]. Kyiv: UOVTs "Orion" [in Ukrainian].

7 Yaroshenko,O.H. (2019). Khimiia. 11 kl.: pidr dlia zakl. zahalnoi serednoi osvity [Chemistry. Gr. 11: textbook for institutions of general secondary education]. Kyiv: UOVTs "Orion" [in Ukrainian].

8 Kodliuk, Ya.P. (2014). Kontseptualni osnovy pobudovy pidruchnyka dlia pochatkovoi shkoly [Conceptual foundations for constructing a textbook for primary school]. Problemy suchasnoho pidruchnyka - Problems of a modern textbook, 14, $284-292$. Retrieved from http://nbuv.gov.ua/UJRN/psp_2014_14_34 [in Ukrainian].

9 Baranovska, O.V. (2020). Suchasnyj pidruchnyk u rusli humanitaryzatsii navchalnoho protsesu: osnovni aktsenty [A modern textbook in line with the humanization of the educational process: the main accents]. Problemy suchasnoho pidruchnyka - Problems of a modern textbook, 25, 5-13 [in Ukrainian].

10 Stará Ja., Chvál M., Starý K. (2017). The Role of Textbooks in Primary Education. E-Pedagogium, IV, 60-69. Retrieved from https://e-pedagogium.upol.cz/pdfs/epd/2017/04/07.pdf

11 Zimnyaya, I.A. (2010). Pedagogicheskaia psikhologiia [Educational psychology]. (3 ${ }^{\text {rd }}$ ed.). Moscow: Moskovskii psikhologosotsialnyi institut; Voronezh: NPO "MODEK" [in Russian].

12 Beilinson, V.G. (2005). Arsenal obrazovaniia: Uchebnaia kniga: proektirovanie i konstruirovanie [Arsenal of education: Textbook. book: design and construction]. (2nd ed.). Moscow: Mnemozina [in Russian].

13 Papajani, J. (2015). The Evaluation of the EFL Textbooks Used in the High Schools of Elbasan, Albania. European Journal of Language and Literature Studies [online], 1, 1, 7-15. http://journals.euser.org/files/articles/ejls_jan_apr_15/Josilda_Papajani.pdf

14 Behnke Y. (2016). How textbook design may influence learning with geography textbooks. Nordidactica-journal of humanities and social science education, 1, 38-62. https://www.diva-portal.org/smash/get/diva2:1047511/FULLTEXT01.pdf;fulltext

\section{Information about the author}

Yaroshenko, Olga Grigorievna - Doctor of Pedagogical Sciences, Professor, full member (academician) of the National Academy of Pedagogical Sciences of Ukraine, Leading researcher, Institute of Higher Education of the National Academy of Educational Sciences of Ukraine, Bastionna Street, 9, 01014, Kyiv, Ukraine; e-mail: yaroshenko_o@ukr.net, https://orcid.org/0000-0003-1555-0526 